\title{
The Sports Film
}

\author{
By Seán Crosson
}

Fall 2015 Issue of KINEMA

\section{THE SPORTS FILM: GAMES PEOPLE PLAY}

The sports film has gained increasing recognition as one of the most important and popular genres in contemporary cinema. Its beginnings lie in the very earliest years of film, when sport provided filmmakers, particularly in the United States, with a popular and dramatic subject for their productions. However, sports films are today arguably more popular than at any point in the history of the genre, evident in the past decade in the commercial and critical success of films such as Million Dollar Baby (2004), The Blind Side (2009) and The Fighter (2010). Bruce Babington's study, The Sports Film, Games People Play is therefore a timely intervention that contributes to the growing body of academic work dedicated to the genre.

As Babington contends in his introduction, sports films are much more complex entities than many people may allow and "should be read with the same intelligence given to, indeed demanded for, other forms of popular generic cinema." While cognizant of sports importance, including in film, in constructions of personal and social identities - be they of class, gender or sexuality - Babington also stresses the affirmative pleasures sport and its representations provide, a crucial consideration in understanding the continuing popularity of the sports film genre. In a revealing vignette, he recalls a passage in the English poet Edmund Blunden's book Cricket Country: "Somewhere I read the last letter of a man who was about to be hanged for a murder, and as I remember it, it bore a postscript, 'No more cricket, George'". Sport can provide transcendent moments in many people's lives that few other experiences can equal, an aspect readily exploited within the sports film genre.

However, the sports film was slow to receive recognition as a significant genre within film history. Babington partly attributes the genre's seeming absence in critical discourse for decades to its hybridity and the inclusion of films featuring sport often in other genres, ranging from the romantic comedy, to the musical, the history film, the art film and many more besides. Indeed, he lists in total 27 sub-categories within which sports films have been found - a list that is by no means exhaustive and does not include the micro genres associated with individual sports from boxing to baseball. The small numbers of sports films to emerge in other national contexts, outside the US, also slowed the genre's recognition. Despite these factors, the increased presence of favourite sports films lists online - as well as the inclusion in 2008 of "Sport" among the American Film Institute's top ten genres of all time - attests to the increasing recognition given to the genre today.

Sports films may differ in their sporting elements, depending on the sports featured, though Babington identifies a "basic plot" across most films featuring sport: "the overcoming of odds by individual or team" often culminating in a climactic last minute victory. This has partly accounted for the popular view of sports film as a particularly predictable and clichéd genre, though Babington details wide variations in this "victory plot" as well as less common variations on a losing plot and the occasional sports films characterized by the "evasion of the winner/loser binarism," evident in the classic surfing film Big Wednesday (1978). Romantic subplots also frequently feature within the genre, as apparent in films from Pat and Mike (1952), to Rocky (1976), and more recent productions Leatherheads (2008) and The Fighter (2010).Babington's analysis, necessarily short given its appearance within the excellent Wallflower Press Short Cuts series, nonetheless provides an illuminating insight into the particularities of the sports film genre, in a variety of contexts. Divided into three major sections, the book considers in parts one and two "Major presences" within the genre before a more detailed analyses of four major sports films in the final section. An important strength of the book is its movement beyond the American canon - often the principal focus for those considering the sports films genre - to include considerations of the genre internationally including in Britain, India, Australia, South Korea and Thailand.

Babington divides the sports film into a number of dominant sub-genres or "presences" as the chapter titles describe them, namely the sports biopic, the sports history film, the sports documentary and the boxing 
film. In considering classic sports biopics such as Knute Rockne All American (1940) and Jim Thorpe All-American (1951), he reflects on the considerable fictionalisation that is part of such work "subject to the inspirational demands on biopics of the time". Whatever differences may exist between particular films within the American sports biopic sub-genre, however, they all respond to specific meanings ascribed to sports in the United States, including sport as a symbol of Americanness and the American Dream. This trajectory featuring Americans moving from the margins to the mainstream of American life recurs across a range of sports films in Hollywood's classical era, including The Pride of the Yankees (1942), Gentleman Jim (1942) as well as the Rockne and Thorpe biopics. In films such as these, as Babington highlights, "Sport...is presented as a powerful validation of American social mobility, proving that in America you can choose to be what you want." As such, athletes depicted in these films are imbued with moral authority.

Since the 1970s in particular, sports films have responded to political and social changes to create sometimes more complex engagements with the lives of athletes. Female athletes for instance, while still under represented, are an increasing feature of the genre, evident in films such as Dawn! (1979), Heart like a Wheel (1983) and Soul Surfer (2011). Babington considers briefly within his study the representation of women, who have played historically a supporting role to the male athletes typically at the centre of sports films. However as social roles evolved in the $20^{\text {th }}$ century, so too did women's roles within sport films with female athletes progressively occupying more central positions. A pioneering film in this respect was George Cukor's Pat and Mike (1952), a work that established the recurring trope of the female athlete/male coach dyad, in which we frequently encounter the at first doubting male coach who, over time, comes to respect the female athlete, whether in the figure of Mike Conovan (Spencer Tracy) in Pat and Mike, Joey Dugan (Tom Hanks) in A League of Their Own (1992) or Frankie Dunn (Clint Eastwood) in Million Dollar Baby. Babington examines a number of aspects of this trope from its reflection of real world conditions, to its continuation and reaffirmation of patriarchal structures.

The sports film genre has also provided since the 1970s a more ambiguous and indeed at times pessimistic perspective on the lives of athletes, epitomized in Martin Scorsese's classic Raging Bull (1980) and more recently Darren Aronofsky's The Wrestler (2008). The sports history film, concerning a distinct historical sporting event, has also emerged as an important sub-genre in this period. Examples include Eight Men Out (1988) and The Miracle of Bern (2003) and films within this sub-genre have been more inclined to be faithful to known facts surrounding sporting events. Ultimately, however, as with most sports films, these productions are subject to what Babington describes as "the popular dramatic film's necessary omissions, contractions and shapings of incidents, and assignments of unrecorded motivations and feelings."

Babington sees the sports documentary as occupying an important place within the sports film genre. He views the format as responding to two principal impulses, the delineation and celebration of sporting motion (which dates back to the origins of film in Eadweard Muybridge's work), and the pursuance of social meanings in sporting phenomena. Often, both impulses are evident within individual films, as in the award-winning basketball themed documentary Hoop Dreams (1993). The making of sports documentaries has also inspired important technical developments in film, most notably the achievements of Leni Riefenstahl's film of the 1936 Berlin Olympics, Olympia (1938), including the use of a rail-propelled camera racing alongside the sprinters featured, and the employment of telescopic lenses and multiple camera angles to capture the dynamism of the athletic events filmed. However, here as elsewhere in the sports documentary, Riefenstahl's film also reveals the thin line between fact and fiction in such representations: a considerable part of her film was not filmed live at the Olympics but rather involved reshoots after the event, including impressive scenes shot onboard boats in the yachting event and the subjective shots of road runners in the marathon. As Babington is keen to alert the reader, "documentary is not restricted to live shooting but may create effects and arguments through artifice".

Of all the sub-genres of the sports film, none have achieved the commercial or critical acclaim of the boxing film. While noting the importance of boxing in early cinema - according to one commentator "it was boxing that created cinema" - Babington identifies the realistic, violent and tragic aspects of boxing as among the main attractions of the sport for filmmakers. Boxing also provides a powerful rendering of the decline of the physical body while simultaneously seeming to offer one of the most attractive vehicles for social mobility among marginalised and various ethnic groups in the United States. Whether depicting the boxer as hero or victim (two dominant categories Babington identifies) boxing films have continued to appeal to audiences 
around the world. One of the strengths of Babington's analysis is his willingness to consider non-western examples of the sub-genre (a rarity in the literature) including the Korean films Champion (2002) and Crying Fist (2005), identifying both their similarities with the dominant American model - in their featuring of the rise to glory trajectory - but also their departure from this standard in the inclusion of a double narrative within Crying Fist which disrupts the individualistic focus of the typical Hollywood film.

The second part of Babington's study explores the sports film as spectacle, finding parallels with the epic, musical and war film. In the sports film, this spectacle is focused on bodies in motion in rule bound contests. However, cinematic depictions of sporting events often suffer by comparison with televisual portrayals. The advent of TV has also increased expectations regarding the depictions of sporting events within films and the development of cinematographic technologies to communicate the dynamism of the events filmed, evident particularly within boxing films such as Rocky (1976) and The Fighter (2010). Indeed televisual coverage itself is frequently incorporated into the diegesis of contemporary sports films to add to the verisimilitude of depictions, including in the boxing-themed film mentioned above.

In his analysis of spectacle, Babington also examines the modes of staging sporting action in films ranging from actors simulating sporting events to the combination of actuality and simulated events. While actors often lack the skills of professional athletes, athletes rarely possess significant acting abilities, evident for example in several of the performances in the poorly received football-themed film Escape to Victory (John Huston, 1981). This need for increasing verisimilitude in contemporary sports film has encouraged the emergence of dedicated companies, such as "reelsports solutions" who assist in the casting of participants with both acting and sporting abilities and in bringing non-players - actors - to convincing levels of skill on screen, including via camera placement and other cinematographic strategies. Reelsports solutions have contributed to a range of sports films including Jerry Maguire (1996), Coach Carter (2005) and Chak De India! (2007) while CGI has also played an increasing role in the contemporary sports film, evident in productions such as Wimbledon (2004), and Ping Pong (2002).

The final section of Babington's volume includes more in-depth studies of four major sports films, Chariots of Fire (1981), Field of Dreams (1989), Any Given Sunday (1999) and Lagaan (2001). In each of these films, he identifies elements that disrupt the more utopian trajectories often associated with sports films. In Chariots, this is evident in unresolved tensions - including between amateurism and professionalism - within the text and the restrained celebration of Jewish runner Harold Abrahams following his victory in the 1924 Olympics 100 metres sprint, implying that sporting success is not the panacea that American sports films often suggest. Babington also identifies disruptive elements within Field of Dreams, a work often viewed as a nostalgic and utopian construction of "America's game" - baseball. However such an interpretation is problematic for him given the film's personification of baseball's nostalgic past in the shape of eight corrupted players associated with the notorious Black Sox Scandal. In terms of non-western cinema, the most detailed analysis given in The Sports Film, Games People Play is of Indian cricket film Lagaan: Once Upon a Time in India (Ashutosh Gowariker, 2001) which Babington views as a sophisticated text that employs cricket and distinctive elements of the Bollywood genre to examine aspects of Indian society and culture, including race, nation, religion and caste.

The remarks of Miami Sharks coach Tony D'Amato (Al Pacino) in Any Given Sunday - "The game's all that matters, because it's pure. Four quarters. You cross a line you score. It's sane. Life isn't. Life's fucked" encapsulates at least part of the powerful appeal of sport. This appeal has attracted filmmakers throughout the history of cinema and across a variety of forms and contexts to sport for inspiration and content. The very popularity and influence of these films has made studies such as The Sports Film, Games People Play crucial in providing academics, students and audiences more generally with the tools to better understand and appreciate one of cinema's most enduring genres.

\section{Reports}

Photo credit: Wallflower Press. 


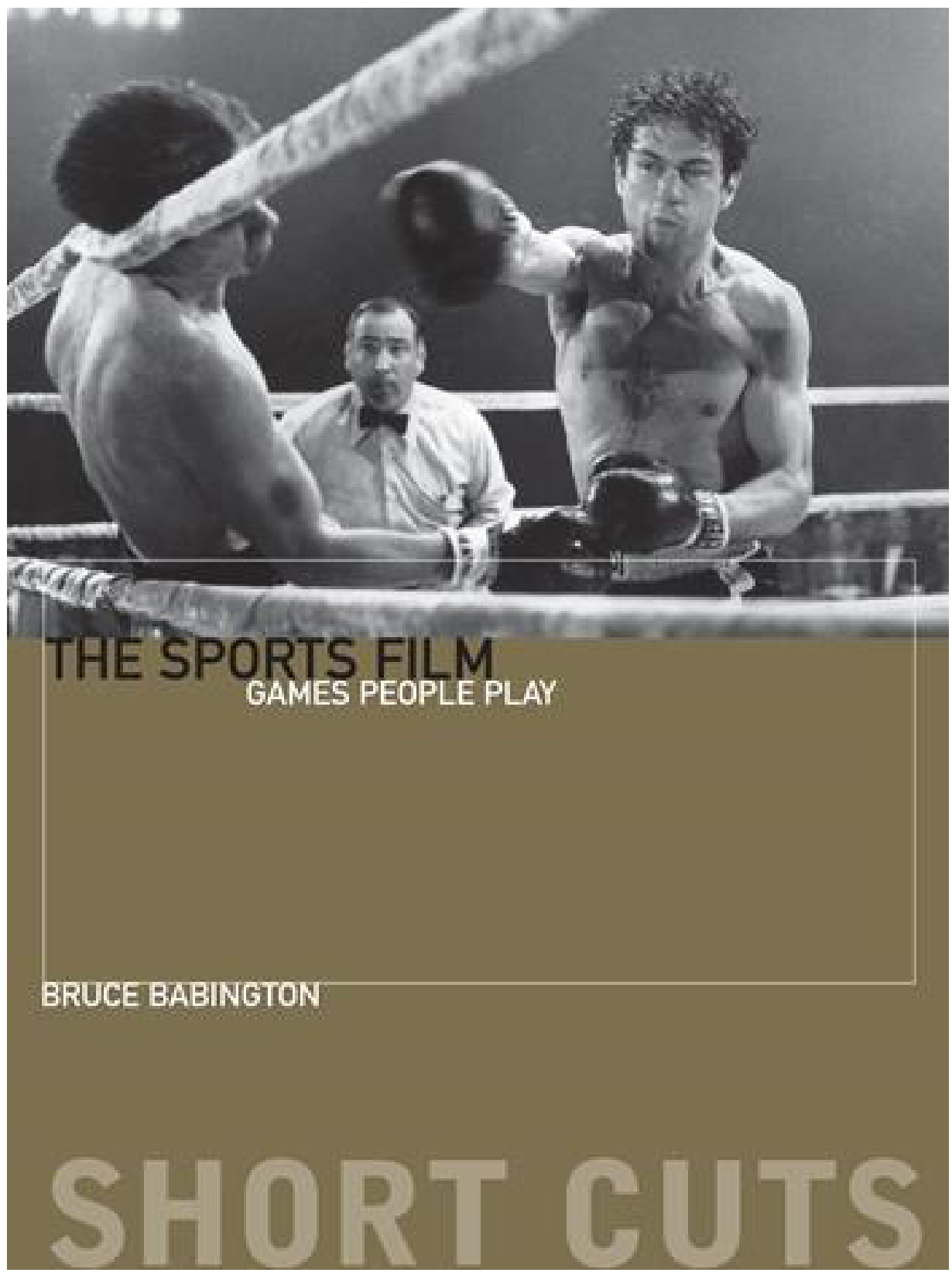

Figure 1: The Sports Film: Games People Play. By Bruce Babington. ๆ Wallflower Press, Short Cuts series, 2014. 


\section{Author Information}

Seán CROSSON is programme director of the MA in Film Studies: Theory and Practice with the Huston School of Film \& Digital Media in NUI Galway. Dr. Crosson's research interests include Irish film, film and sport, and the relationship between music and poetry. He is the author of a study of the sports film genre, Sport and Film (Routledge, 2013). 